\title{
Physicochemical properties and protease activities of microencapsulated pineapple juice powders by spray drying process
}

\author{
Hye-Mi Park, Ho-Yong Chae, Joo-Heon Hong* \\ Department of Food Science and Technology, Catholic University of Daegu, Gyeongsan 712-702, Korea
}

\section{분무건조공정을 이용한 파인애플 착즙액 미세캡슐 분말의 물리화학적 특성 및 protease 활성}

\author{
박혜미 · 채호용 · 홍주헌* \\ 대구가톨릭대학교 식품공학전공
}

\begin{abstract}
The physicochemical properties and protease activities of spray-dried pineapple juice powders were investigated. The $\mathrm{pH}$, soluble solids, and protease activity of the pineapple juice were $\mathrm{pH} 5.43,12.8^{\circ} \mathrm{Brix}$, and $4.82 \mathrm{unit} / \mathrm{mL}$, respectively. The optimum $\mathrm{pH}$ and temperature of the protease activity from pineapple juice were $\mathrm{pH} 7.0$ and $50^{\circ} \mathrm{C}$, respectively. The microencapsulation of pineapple juice was achieved using maltodextrin and alginic acid through spray-drying. The $L$ value and moisture content of the spray-dried powder were higher than those of the freeze-dried powder. The particle size of the freeze-dried powder $(501.57 \mu \mathrm{m})$ was higher than that of the spray-dried powder (42.58-53.32 $\mathrm{\mu m})$. The water absorption and water solubility of the powders were $0.41-0.87$, and $90.45-99.76 \%$, respectively. When compared, the protease activities were found to be in the following order : FD (1,297.47 unit/g) $>$ SD-MA-1 (692.08 unit/g) > SD-MA-2 (664.66 unit/g) > SD-MA-3 (642.65 unit/g) > SD-M (633.51 unit/g). In the in vitro dissolution study measurements were conducted for $4 \mathrm{hr}$ in $\mathrm{pH} 1.2$ simulated gastric fluid and $\mathrm{pH}$ 6.8 simulated intestinal fluid, using a dissolution tester at $37^{\circ} \mathrm{C}$ in $50 \mathrm{rpm}$. The protease survival of the 3.74-15.69\% microencapsulated pineapple juice powders improved with an increase in the treatment concentration of alginic acid.
\end{abstract}

Key words : pineapple, spray drying, microencapsulation, protease activities, physicochemical properties

\section{서 론}

최근 국민소득의 향상과 더불어 식생활 형태 또한 곡류 중심의 소비에서 육류 중심의 소비로 바뀌면서 육류 및 육제품의 수요가 매년 증가되고 있다 $(1,2)$. 이러한 식생활 형태의 변화로 육제품의 품질향상 및 소화개선에 도움을 주는 단백질 분해력에 대한 소비자들의 관심이 증대되고 있다. 단백질 분해효소를 이용하는 방법은 파인애플(3), 파 파야(4), 무화과(5), 키위(6) 및 배(7)와 같은 많은 식물성

*Corresponding author. E-mail : jhhong@cu.ac.kr Phone : 82-53-850-3218, Fax: 82-53-850-3218

Received 15 January 2015; Revised 29 January 2015; Accepted 29 January 2015.

Copyright (c) The Korean Society of Food Preservation. All rights reserved.
원료에 함유되어 있는 효소를 대상으로 하고 있는데, 추출 원이 자연에서 얻은 것인 관계로 식품첨가물로서 안전하여 많이 이용되어지고 있다.

파인애플(Ananas comosus L. Merr.)은 파인애플과에 속 하는 외떡잎식물의 열매로서 특유의 신선한 맛과 향으로 인기가 높아 세계의 많은 지역에서 소비되는 과일이며, 칼 슘, 인, 철 등의 무기질 이외에도 비타민 $\mathrm{A}, \mathrm{B}$ 와 $\mathrm{C}$ 의 풍부한 공급원이다(8). 특히 파인애플에 고농도로 함유되어 있는 단백질 분해효소(protease)인 브로멜라인(bromelain)은 연 육제, 보조 소화제, 소염제 및 항혈청 응고제로서의 효과가 연구되어 있으며(9-12), 안정성이 매우 높고 부작용 및 독성 이 없어 신체 내 내성이 생기지 않는다(13). 그러나 브로멜 라인은 단백질로 이루어져 있어 온도, $\mathrm{pH}$ 및 미생물에 의한 변질이 쉽게 이루어지기 때문에 품질유지가 어렵고, 섭취 시 인체 내 소화모델에 대한 안정성이 떨어져 안정성 개선 
이 필요하다고 사료된다.

미세캡슐(microencapsulated powder)은 미세한 포장 단위 를 말하며, 크기는 수 $\mu \mathrm{m}$ 단위에서 수 $\mathrm{mm}$ 로 다양하며, 모양은 구형이 이상적으로 가공적성이 좋은 분말이다. 미 세캡슐화 기술은 고체, 액체, 기체상의 물질을 특정 조건 하에서 조절된 속도로 내용물을 방출할 수 있도록 어떤 물질이나 조직내부에 포장하는 기술이다(14). 특히 분무건 조에 의한 미세캡슐화는 상업화된 방법 중 가장 보편화 된 것으로 그 생산량도 가장 많아 여러 분야에서 다양한 목적으로 이용되고 있다 $(15,16)$. 분무건조는 액상의 시료를 뜨거운 매체 속에서 분무하여 건조된 분말 형태의 시료를 얻게 되는 방식으로 건조시간이 아주 짧아 열에 약한 물질 도 건조가 가능하며, 용해성과 유동성이 좋은 구상 분말 제품을 제조할 수 있다(17). 또한 건조온도가 $130 ~ 300{ }^{\circ} \mathrm{C}$ 로 비교적 높은 온도에서도 원료가 열에 노출되는 시간은 5 20초 내외로 열에 의한 성분의 변화가 미미하여 기능성 소재산업에서 동결건조와 함께 가장 많이 사용되어지는 방법이다(18). 분무건조된 입자는 피복물질의 조성에 의해 그 특성이 결정되는데, 피복물질은 주로 전분, 사이클로덱 스트린, 말토덱스트린, 셀룰로오스 및 다양한 다당류가 전 통적으로 이용되고 있다. 말토덱스트린은 D-glucose가 1차 적으로 1-4 결합으로 연결되어 있는 비영양원성 다당류로 서 가격이 저렴하여 분무건조시 피복물질로서 많이 이용되 고 있으며, 산소투과도를 감소시키는 특성이 있어 항산화 제 없이도 안정성이 우수하다(19). 또한 알긴산은 낮은 $\mathrm{pH}$ 에서 수축이 일어나고 중성에서 팽윤 및 분해가 일어남으로 써, 산성 치환기의 영향을 효과적으로 차단하고 유용물질 방출을 조절 할 수 있다(20).

본 연구에서는 파인애플에 고농도로 함유되어 있는 단백 질 분해효소인 브로멜라인을 식품산업분야에서 기능성 소 재로 이용하고자 피복물질로 말토덱스트린과 알긴산을 이 용하여 분무건조공정에 의해 미세캡슐을 제조하였으며, 물 리화학적 특성 및 protease 활성을 in vitro 인체 내 소화모델 을 이용하여 조사하였다.

\section{재료 및 방법}

\section{실험재료}

본 실험에 사용된 파인애플(Ananas comosus (L.) Merr.) 은 필리핀산으로 2014년 6월 경상북도 경산시 소재의 마트 에서 구입하여 사용하였다. 미세캡슐화를 위한 피복물질은 말토덱스트린(malto-dextrin, Baolingbao biology Co., Ltd., Shandong, China)과 알긴산(alginic acid, Sigma-Aldrich Co., St. Louis, MO, USA)을 사용하였다.

착즙액의 제조

파인애플의 껍질을 박피하고 가식부분을 잘게 썬 다음
분쇄기(FM-909W, Hanil Co., Sejong, Korea)로 분쇄한 후 여과포로 착즙하였다. 착즙액은 불순물을 제거하기 위하여 원심분리기(VS-6000CFN, Vision scientific Co., Ltd., Bucheon, Korea)를 이용하여 $4^{\circ} \mathrm{C}, 3,000 \mathrm{rpm}$ 에서 10 분간 원심분리 한 후 상등액을 Whatman No. 1 로 여과한 다음 $4{ }^{\circ} \mathrm{C}$ 의 암소에 보관하면서 실험에 사용하였다.

\section{Protease 활성 측정}

Protease 활성 측정은 Kunitz법(21)을 변형하여 측정하였 다. $0.2 \mathrm{M}$ sodium phosphate 완충용액 $(\mathrm{pH} 7.0) 1.5 \mathrm{~mL}$ 에 시료 $0.5 \mathrm{~mL}$ 를 취한 후 $0.6 \%$ casein 용액(w/v, Duksan pure chemicals Co., Ltd., Ansan, Korea) $0.5 \mathrm{~mL}$ 를 가하여 진탕 항온수조(BS-31, Jeio tech Co., Ltd., Seoul, Korea)를 이용하 여 $37^{\circ} \mathrm{C}, 100 \mathrm{rpm}$ 에서 20 분간 반응시킨 후 $0.44 \mathrm{M}$ trichloroacetic acid(TCA, Acros organics, Geel, Belgium) 2.0 $\mathrm{mL}$ 를 넣어 반응을 중지시키고 반응액을 원심분리기 (1236MG, GYROZEN Co., Ltd., Daejeon, Korea)를 이용하 여 $3,000 \mathrm{rpm}$ 에서 10 분간 원심분리 하였다. 상등액 $1.5 \mathrm{~mL}$ 를 취하여 $0.55 \mathrm{M}$ sodium carbonate anhydrous $\left(\mathrm{Na}_{2} \mathrm{CO}_{3}\right)$ $1.0 \mathrm{~mL}$ 와 $1 \mathrm{~N}$ Folin ciocalteu 용액(Sigma-Aldrich Co., St. Louis, MO, USA) $1.0 \mathrm{~mL}$ 를 가하여 $37^{\circ} \mathrm{C}$ 에서 30 분간 발색반 응시킨 다음 분광광도계(Ultraspec-2100pro, Amersham Co., Uppsala, Sweden)를 이용하여 $660 \mathrm{~nm}$ 에서 흡광도를 측정하 였다. Protease 활성은 tyrosine(Sigma-Aldrich Co., St. Louis, $\mathrm{MO}, \mathrm{USA})$ 을 정량하여 작성한 표준곡선으로부터 계산하였 으며, 활성단위(unit)는 1 분당 $1 \mathrm{\mu g}$ 의 tyrosine을 생성하는 효소의 양으로 정의하였다.

\section{$\mathrm{pH}$ 및 온도 특성}

Protease 활성에 미치는 $\mathrm{pH}$ 의 영향을 검토하기 위하여 완충용액은 $0.2 \mathrm{M}$ citrate 완충용액 $(\mathrm{pH} 3.0 \sim 6.0), 0.2 \mathrm{M}$ sodium phosphate 완충용액 $(\mathrm{pH} 6.0 \sim 8.0)$ 및 $0.2 \mathrm{M}$ Tris-HCl 완충용액(pH 8.0 9.0)을 이용하여 기질을 제조하였으며, 기 질과 효소반응은 $37^{\circ} \mathrm{C}$ 에서 20 분간 반응한 후 측정하였다.

Protease 활성에 미치는 온도의 영향은 $0.2 \mathrm{M}$ sodium phosphate 완충용액 $(\mathrm{pH}$ 7.0)을 이용하여 기질을 제조한 후 $20^{\circ} \mathrm{C}$ 에서 $80^{\circ} \mathrm{C}$ 의 온도범위에서 20 분간 기질과 효소를 반응 한 후 측정하였다. 이 외의 반응 조건은 protease 활성 측정 방법과 동일하게 진행하였다.

\section{미세캡슐화}

분무건조공정을 이용한 미세캡슐화는 파인애플 착즙액 $300 \mathrm{~mL}$ 에 $20 \%(\mathrm{w} / \mathrm{v})$ 말토덱스트린 및 1, 2, 3\%(w/v) 알긴산 을 첨가한 다음 고압균질기(HG-15D, DAIHAN scientific Co., Ltd., Wonju, Korea)를 이용하여 $6,000 \mathrm{rpm}$ 에서 20 분간 균질화하였다. 제조된 균질액은 주입 온도 $160^{\circ} \mathrm{C}$, 방출 온도 $100^{\circ} \mathrm{C}$ 로 설정하였고, 분무속도는 $16,000 \mathrm{rpm}$ 에서 시료 공 
급속도는 $12 \mathrm{~mL} / \mathrm{min}$ 의 조건으로 아토마이져(atomizer)가 장착된 분무건조기(KL-8, Seogang engineering Co., Ltd., Cheonan, Korea)를 이용하여 미세캡슐화 하였으며, $-70^{\circ} \mathrm{C}$ 이하의 암소에 보관하면서 분석용 시료로 사용하였다. 대 조구로는 피복물질을 첨가하지 않고 동결건조 (FreeZone-2.5, Labconco Co., Kansas, MO, USA)를 이용하여 건조한 분말 을 사용하였다.

\section{수분함량 및 색도 측정}

수분함량은 미세캡슐 분말을 페트리디쉬에 담아 적외선 수분측정기(MB-45, Moisture analyzer, INC., Ohaus, USA) 를 이용하여 $105^{\circ} \mathrm{C}$ 에서 분말의 수분함량이 항량에 도달할 때까지 건조하여 측정하였다. 색도 측정은 표준색도가 $\mathrm{L}=95.5, \mathrm{a}=0.18, \mathrm{~b}=0.32$ 로 보정된 색도계(CR-300, Minolta Co., Osaka, Japan)를 이용하여 L값(lightness), a 값(redness), $\mathrm{b}$ 값(yellowness)으로 측정하였다.

\section{입자크기 및 입자표면구조 분석}

입자크기는 미세캡슐 분말을 isopropyl alcohol에 분산시켜 레이저입도분석기(LS-13-320, Beckman coulter, Fullerton, $\mathrm{CA}, \mathrm{USA}$ )를 이용하여 측정하였다.

입자표면구조는 각 시료에 gold ion coating한 후 주사형 전자현미경(S-4800, Hitachi high-Technologies Co., Tokyo, Japan)을 이용하였으며, 전자현미경을 이용한 관찰은 3.0 $\mathrm{kV}$ 에서 500 배 비율로 관찰하였다.

\section{수분흡수지수(WAI) 및 수분용해지수(WSI) 측정}

수분흡수지수(water absorption index, WAI) 및 수분용해 지수(water solubility index, WSI) 측정은 phillips(22)의 방 법을 변형하여 측정하였다. 미세캡슐화 분말 $0.5 \mathrm{~g}$ 에 20 $\mathrm{mL}$ 증류수를 첨가하여 $3,000 \mathrm{rpm}$ 에서 20 분간 원심분리 한 후 침전물은 수분흡수지수로 사용하였으며, 상등액은 미리 무게를 구한 수기에 분리하여 $105^{\circ} \mathrm{C}$ 에서 4 시간 동안 건조시킨 고형분을 수분용해지수로 사용하여 아래와 같 이 계산하였다.

$$
\begin{aligned}
& \text { 수분흡수지수(WAI) }=\frac{\text { 침 전물의 양 }}{\text { 시료의 양 }} \\
& \text { 수분용해지수(WSI, \%) }=\frac{\text { 상등 액고형분 의 양 }}{\text { 시료의 양 }} \times 100
\end{aligned}
$$

\section{in vitro 인체 내 소화모델 측정}

in vitro 인체 내 소화모델에 대한 protease 활성의 안정성 을 검토하기 위하여 대한약전에 따라 인공위액 및 인공장액 을 제조하였으며, 인체 내 소화모델에 대한 실험방법은 Hur 등(23)의 방법을 변형하여 측정하였다. 시료 $2.0 \mathrm{~g}$ 에 인공위 액 $18 \mathrm{~mL}$ 를 첨가하여 진탕 항온수조를 이용하여 $37^{\circ} \mathrm{C}, 50$ $\mathrm{rpm}$ 에서 2시간 반응시킨 후 인공장액 $20 \mathrm{~mL}$ 를 첨가하여 $37^{\circ} \mathrm{C}, 50 \mathrm{rpm}$ 에서 2 시간 반응시킨 후 protease 활성 측정용 시료로 사용하였다.

\section{통계처리}

실험결과는 3회 반복으로 행하여 평균 \pm 표준편차로 나타 내었고 SPSS(19.0, SPSS Inc., Chicago, IL, USA)를 이용하 여 분산분석(ANOVA)을 실시하였으며, 각 측정 평균값의 유의성 $(\mathrm{p}<0.05)$ 은 Duncan's multiple range test로 검정하였다.

\section{결과 및 고찰}

파인애플 착즙액의 특성

파인애플 착즙액의 $\mathrm{pH}$, 가용성 고형분 및 protease 활성 은 Table 1 과 같다. $\mathrm{pH}$ 는 5.43 이었고 ${ }^{\circ} \mathrm{Brix}$ 는 12.80 으로 높은 당도를 나타내어 분무건조를 이용한 미세캡슐 분말 제조시 수율이 높을 것으로 판단된다. Protease 활성은 $4.82 \mathrm{unit} / \mathrm{mL}$ 로 나타났으며, 활성단위(unit)는 1 분당 $1 \mathrm{\mu g}$ 의 tyrosine을 생성하는 효소의 양으로 정의하였다. Yoo 등(24)은 파인애 플 유래 조효소액의 protease 활성 측정 결과 $0.57 \mathrm{unit} / \mathrm{mL}$ 라 고 보고하여 본 연구보다 낮은 활성을 나타내었는데, 이는 조효소액의 추출방법 및 활성단위의 정의가 다르기 때문으 로 사료된다.

Table 1. $\mathrm{pH}$, soluble solids, and protease activity of pineapple juice

\begin{tabular}{cccc}
\hline Sample & $\mathrm{pH}$ & ${ }^{\circ}$ Brix & $\begin{array}{c}\text { Protease activity } \\
\text { (unit/mL) }\end{array}$ \\
\hline Pineapple juice & $5.43 \pm 0.01$ & $12.80 \pm 0.00$ & $4.82 \pm 0.10$ \\
\hline \multicolumn{2}{l}{ All values are means $\pm \mathrm{SD}(\mathrm{n}=3)}$.
\end{tabular}

All values are means $\pm \mathrm{SD}(\mathrm{n}=3)$.

파인애플 착즙액의 protease 활성에 미치는 $\mathrm{pH}$ 및 온도의 영향을 검토한 결과는 Fig. 1과 같다. $\mathrm{pH}$ 의 경우 $0.2 \mathrm{M}$ sodium phosphate 완충용액 $(\mathrm{pH}$ 7.0)에서 가장 높은 효소 활성을 나타내었으며 $\mathrm{pH} 3$ 에서는 효소 활성이 $1 \%$ 이하 로 확인 되었다. Bai 등(1)은 배, 무화과, 파인애플, 파파야에 서 추출한 조효소에 대한 $\mathrm{pH}$ 의 영향을 조사한 결과 $\mathrm{pH}$ 5.0 8.0에서 안정하였고, $\mathrm{pH} 7.0$ 에서 가장 높은 활성을 나 타내었다고 보고하였다. 온도의 경우 온도가 증가함에 따 라 활성이 점차 증가하였으며 $50^{\circ} \mathrm{C}$ 에서 가장 높은 활성을 나타내었고, $60^{\circ} \mathrm{C}$ 이후 효소활성이 감소하는 경향을 나타 내었으며 이는 기존 연구결과와 유사하였다 $(1,24) . \mathrm{Kim}$ 등 (25)은 키위 유래 조효소액의 경우 $60^{\circ} \mathrm{C}$ 에서 약 $30 \%$ 정도의 활성만이 잔존한다고 보고하였으나 본 연구의 파인애플 착즙액은 $60^{\circ} \mathrm{C}$ 에서 $97 \%$ 의 활성을 나타내었고 $70^{\circ} \mathrm{C}$ 에서는 $50 \%$ 의 활성을 나타내어 파인애플 착즙액의 protease 활성 이 열에 더 안정함을 확인하였다. 
(A)

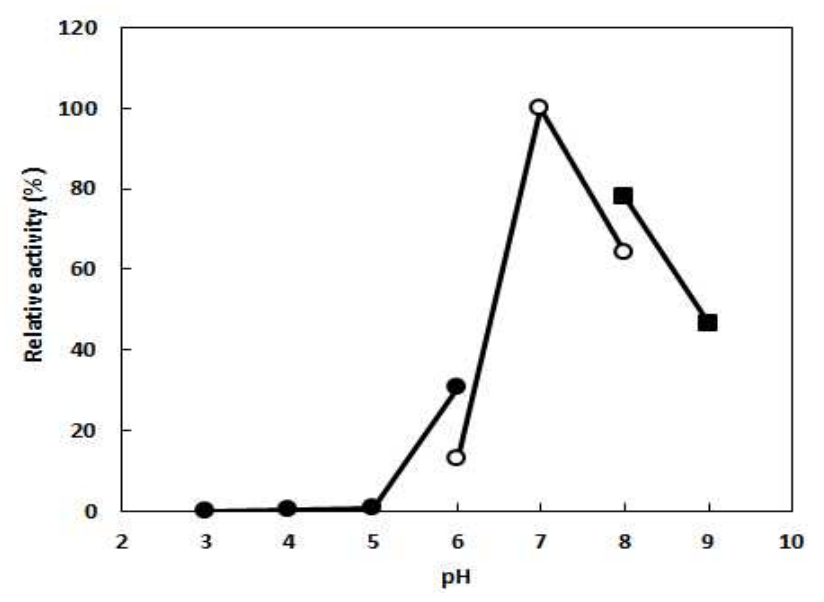

(B)

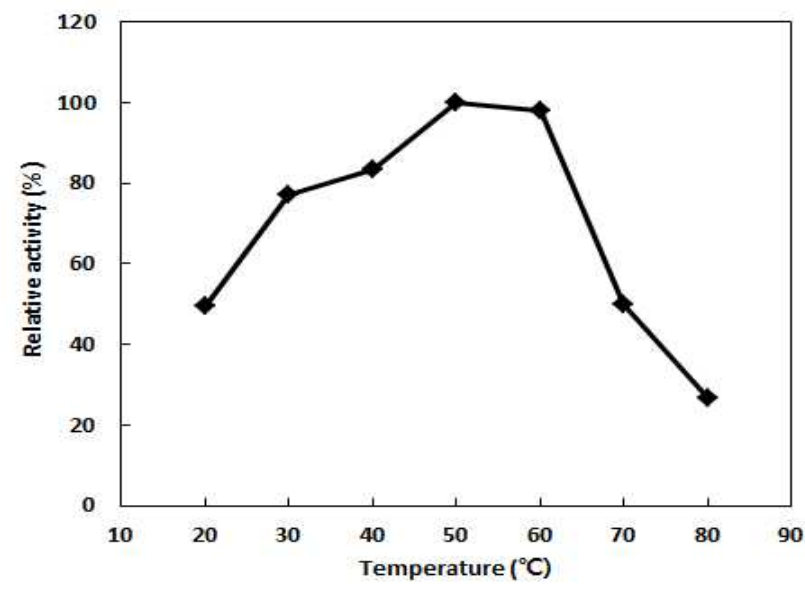

Fig. 1. Effect of $\mathrm{pH}(\mathrm{A})$ and temperature (B) on the protease activity from pineapple juice.

The reactions were performed in $0.2 \mathrm{M}$ citrate buffer ( $\mathrm{pH} 3.0 \sim 6.0$ ), $0.2 \mathrm{M}$ sodium phosphate buffer $(\circlearrowleft, \mathrm{pH} 6.0 \sim 8.0)$ and $0.2 \mathrm{M}$ Tris-HCl buffer ( $\mathbf{\square}, \mathrm{pH} 8.0 \sim 9.0$ ) containing $0.6 \%$ substrate and pineapple juice at $37^{\circ} \mathrm{C}$ for $20 \mathrm{~min}$.

미세캡슐 분말의 수분함량, 색도, 입자크기 및 입자표면구조 파인애플 착즙액 미세캡슐 분말의 수분함량, 색도 및 입 자크기는 Table 2 와 같다. 수분함량은 동결건조 분말에서 $3.02 \%$ 로 가장 낮은 함량을 나타내었으며, 분무건조 미세캡 슐 분말에서 $3.35 ~ 3.75 \%$ 로 알긴산 첨가량이 증가할수록 낮아지는 경향이었다. $\mathrm{Kim}$ 등(26)의 미역과 다시마 분무건 조 분말의 수분함량이 각각 $8.57 \%$ 및 $11.11 \%$ 로 나타났으 며, Jeong 등(27)의 분무건조 탁주분말의 수분함량이 $6.64 \%$ 로 나타나 본 연구의 분무건조 미세캡슐 분말이 낮은 수분 함량을 나타냄을 확인할 수 있었다. 색도는 분무건조 미세 캡슐 분말이 동결건조 분말에 비하여 $\mathrm{L}$ 값 및 $\mathrm{a}$ 값은 낮고 $\mathrm{b}$ 값은 높은 경향을 나타내었는데 특히 말토덱스트린에 알 긴산 $3 \%$ 를 첨가한 분말은 $\mathrm{L}$ 값, $\mathrm{a}$ 값 및 $\mathrm{b}$ 값이 각각 95.63 , -1.85 및 10.35 를 나타내어 선명한 노란색을 보여주었다. 입자크기의 경우 동결건조 분말 $(501.57 \mu \mathrm{m})$ 에 비하여 분무
건조 미세캡슐 분말이 42.58 53.32 $\mu \mathrm{m}$ 로 유의적으로 낮은 크기를 나타내었으며, 말토덱스트린에 알긴산 첨가량이 높 아질수록 입자크기가 커지는 경향이었다. Hwang 등(28)은 일반적으로 1 200 $\mu \mathrm{m}$ 의 분말을 미세캡슐 범위로 분포한다 고 보고하였으며, Rosenberg 등(29)은 입자크기가 작을수록 내부 물질을 포접하는데 유리하다고 한 연구결과에 따라 동결건조 분말보다 분무건조 미세캡슐 분말에서 in vitro 인체 내 소화모델에서의 안정성 향상에 기여할 것으로 기대 된다. 미세캡슐 분말의 입자표면구조를 측정한 결과 동결 건조 분말은 구형이 형성되지 않고 엉김현상으로 인해 정확 한 측정이 어려웠으나, 분무건조 미세캡슐 분말의 경우 전 반적으로 구형의 모양을 보여주어 분말 흐름성이 양호할 것으로 판단된다(Fig. 2). 분무건조 미세캡슐 분말에서 말토 덱스트린을 첨가한 분말은 입자표면에 굴곡이 많은 구형을 나타내었으나 말토덱스트린에 알긴산이 첨가된 경우, 첨가 량이 높아질수록 굴곡이 적은 구형을 나타냄을 확인하였 다. $\operatorname{Kim}$ 등(30)은 입자표면의 굴곡이 건조 과정에서 입자들 이 수축함에 따른 현상이라고 보고하였는데, 이에 본 연구 의 분무건조에 의한 파인애플 착즙액 미세캡슐 제조시 알긴 산의 첨가량이 높아질수록 입자표면의 수축현상이 완화되 는 것으로 판단된다.

Table 2. Moisture, color and particle size of microencapsulated pineapple juice powders

\begin{tabular}{|c|c|c|c|c|c|}
\hline \multirow{2}{*}{ Samples ${ }^{1)}$} & \multirow{2}{*}{$\begin{array}{c}\text { Moisture } \\
(\%)\end{array}$} & \multicolumn{3}{|c|}{ Color } & \multirow{2}{*}{$\begin{array}{l}\text { Particle size } \\
\quad(\mu \mathrm{m})\end{array}$} \\
\hline & & $\mathrm{L}$ value & a value & $\mathrm{b}$ value & \\
\hline FD & $3.02 \pm 0.02^{\mathrm{e}}$ & $91.76 \pm 0.06^{\mathrm{e}}$ & $-2.35 \pm 0.06^{\mathrm{c}}$ & $12.44 \pm 0.03^{\mathrm{a}}$ & $501.57 \pm 24.92^{\mathrm{a}}$ \\
\hline SD-M & $3.65 \pm 0.01^{\mathrm{c}}$ & $97.70 \pm 0.26^{\mathrm{a}}$ & $-1.99 \pm 0.02^{\mathrm{b}}$ & $8.37 \pm 0.01^{\mathrm{d}}$ & $42.58 \pm 0.32^{\mathrm{b}}$ \\
\hline SD-MA-1 & $3.75 \pm 0.01^{\mathrm{a}}$ & $97.16 \pm 0.16^{b}$ & $-1.97 \pm 0.01^{b}$ & $8.19 \pm 0.39^{d}$ & $52.19 \pm 1.02^{\mathrm{b}}$ \\
\hline SD-MA-2 & $3.69 \pm 0.01^{\mathrm{b}}$ & $96.67 \pm 0.25^{\mathrm{c}}$ & $-1.96 \pm 0.01^{b}$ & $9.62 \pm 0.49^{c}$ & $52.70 \pm 0.19^{b}$ \\
\hline SD-MA-3 & $3.35 \pm 0.01^{\mathrm{d}}$ & $95.63 \pm 0.24^{\mathrm{d}}$ & $-1.85 \pm 0.04^{a}$ & $10.35 \pm 0.41^{b}$ & $53.32 \pm 0.40^{\mathrm{b}}$ \\
\hline
\end{tabular}

${ }^{1)} \mathrm{FD}$, freeze-dried powder; SD-M, spray-dried powder added $20 \%$ maltodextrin; SD-MA-1, spray-dried powder added 20\% maltodextrin and $1 \%$ alginic acid; SD-MA-2, spray-dried powder added $20 \%$ maltodextrin and $2 \%$ alginic acid; SD-MA-3, spray-dried powder added 20\% maltodextrin and 3\% alginic acid.

${ }^{2)}$ Means \pm SD ( $n=3$ ) within each column (a-e) followed by the same letter are not significantly different $(\mathrm{p}<0.05)$.

미세캡슐 분말의 수분흡수지수(WAI) 및 수분용해지수(WSI)

미세캡슐 분말의 수분흡수지수 및 수분용해지수는 Table 3 과 같다. 분말의 수분흡수지수 및 수분용해지수는 식품산 업 활용 측면에서 중요한 가공적성 요인으로 알려져 있으며 (31), 특히 분말의 안정성 및 붕해력과 밀접한 관련이 있다. 수분흡수지수는 말토덱스트린에 알긴산을 $3 \%$ 첨가한 분무 건조 미세캡슐 분말에서 0.41 로 가장 낮은 지수를 나타내었 으며 동결건조 분말에서 0.87 로 가장 높은 지수를 나타내었 다. 흡습성이 클수록 고화현상의 발생이 용이하여 저장안 정성이 낮은 것으로 간주되는데(32), 분무건조 미세캡슐 


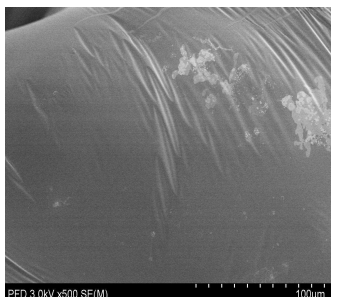

(A) $\mathrm{FD}^{1}$

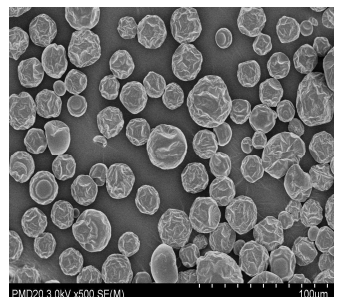

(B) SD-M

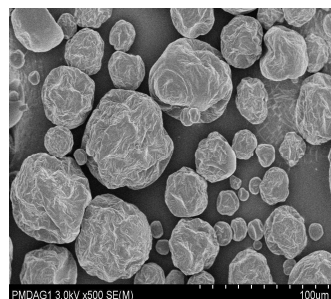

(C) SD-MA-1

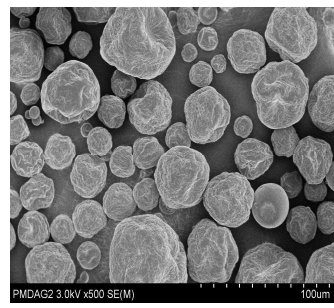

(D) SD-MA-2

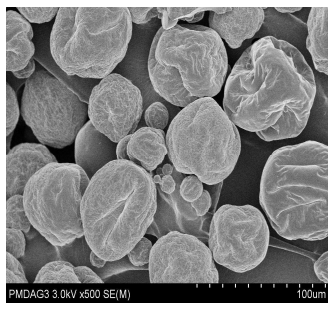

(E) SD-MA-3

Fig. 2. Scanning electron microscope $(3.0 \mathrm{kV} \times 500)$ of microencapsulated pineapple juice powders.

FD, freeze-dried powder; SD-M, spray-dried powder added $20 \%$ maltodextrin; SD-MA-1, spray-dried powder added $20 \%$ maltodextrin and $1 \%$ alginic acid; SD-MA-2, spray-dried powder added 20\% maltodextrin and 2\% alginic acid; SD-MA-3, spray-dried powder added $20 \%$ maltodextrin and 3\% alginic acid.

Table 3. Water absorption index (WAI) and water solubility index (WSI) of microencapsulated pineapple juice powders

\begin{tabular}{ccc}
\hline Samples $^{1)}$ & Water absorption index & $\begin{array}{c}\text { Water solubility index } \\
(\%)\end{array}$ \\
\hline FD & $0.87 \pm 0.01^{22}$ & $90.45 \pm 0.19^{\mathrm{b}}$ \\
SD-M & $0.74 \pm 0.01^{\mathrm{b}}$ & $99.76 \pm 0.21^{\mathrm{a}}$ \\
SD-MA-1 & $0.65 \pm 0.03^{\mathrm{c}}$ & $99.35 \pm 0.94^{\mathrm{a}}$ \\
SD-MA-2 & $0.48 \pm 0.02^{\mathrm{d}}$ & $98.41 \pm 1.56^{\mathrm{a}}$ \\
SD-MA-3 & $0.41 \pm 0.10^{\mathrm{d}}$ & $98.22 \pm 3.77^{\mathrm{a}}$ \\
\hline
\end{tabular}

${ }^{1)} \mathrm{FD}$, freeze-dried powder; SD-M, spray-dried powder added $20 \%$ maltodextrin; SD-MA-1, spray-dried powder added 20\% maltodextrin and 1\% alginic acid; SD-MA-2, spray-dried powder added 20\% maltodextrin and $2 \%$ alginic acid; SD-MA-3, spray-dried powder added $20 \%$ maltodextrin and $3 \%$ alginic acid.

${ }^{2)}$ Means \pm SD ( $=3$ ) within each column (a-d) followed by the same letter are not significantly different $(\mathrm{p}<0.05)$.

분말은 알긴산 첨가량이 $1 \%$ 에서 $3 \%$ 로 높아질수록 수분 흡수지수는 각각 $0.65,0.48$ 및 0.41 로 낮아지는 경향을 나타 내어 저장안정성이 향상됨을 확인하였다. 특히 말토덱스트 린에 알긴산 $3 \%$ 첨가한 미세캡슐 분말에서 0.41 의 수분흡 수지수를 나타내어 수분에 대한 분말의 안정성이 높을 것으 로 판단된다.

수분용해지수는 동결건조 분말에서 $90.45 \%$ 로 가장 낮은 지수를 나타내었으며 분무건조 미세캡슐 분말에서 98.22 $99.76 \%$ 로 나타나 우수하였다. 분무건조 미세캡슐 분말에 서 알긴산의 첨가량이 높아질수록 수분용해지수는 낮아졌 으나 통계적으로 유의적인 차이는 나타나지 않았다. Kim 등(33)은 건조방법에 따른 양파분말 입자의 용해도를 측정 한 결과 입자크기가 커질수록 수분용해지수가 낮아진다고 보고하여 본 연구결과와 유사하였다. 이에 알긴산을 파인 애플 착즙액 미세캡슐 제조시 피복물질로 활용할 경우 수분 의 흡습성 및 용해성을 고려하였을 때, $2 ~ 3 \%$ 의 비율로 혼합 하여 사용하여야 흡습성이 낮고 용해성이 양호한 분말을 얻을 수 있을 것이라 판단된다.

미세캡슐 분말의 protease 활성 및 in vitro 인체 내 소화모델 미세캡슐 분말의 protease 활성 및 in vitro 인체 내 소화모 델에 대한 protease 활성의 안정성을 검토한 결과는 Table
4와 같다. Protease 활성은 동결건조 분말에서 $\mathrm{g}$ 당 $1,297.47$ unit으로 가장 높은 활성을 나타내었으며, 분무건조 미세캡 슐 분말에서 말토덱스트린 단독 첨가시 $\mathrm{g}$ 당 633.51 unit으로 가장 낮은 활성을 나타내었다. 특히 미세캡슐 분말에서 말 토덱스트린에 알긴산 첨가량이 증가할수록 692.08 unit/g에 서 642.65 unit/g으로 낮아지는 경향을 나타내었다. Protease 의 경우 $\mathrm{pH}$ 및 온도가 활성에 중요한 요소로 보고되어져 있는데, 본 실험에 이용된 파인애플 착즙액은 $0.2 \mathrm{M}$ sodium phosphate 완충용액 $(\mathrm{pH}$ 7.0)에서 가장 높은 효소 활성을 나타냈으며 $\mathrm{pH} 3 \sim 5$ 에서는 효소활성이 $1 \%$ 이하임이 확인 되었다. Hur 등(23)의 연구에 따르면 인체 내 소화모델에 대한 연구에서 위액은 $\mathrm{pH}$ 3이하, 장액의 경우 $\mathrm{pH} 5 \sim 8$ 범위 를 나타낸다고 보고되고 있어 미세캡슐의 인체 내 소화모델 에 대한 protease 활성 안정성을 검토하고자 하였다. 미세캡 슐 분말의 in vitro 인체 내 소화모델에 대한 protease 활성의 안정성을 검토한 결과 동결건조 분말의 경우 효소 활성이 나타나지 않았으나, 분무건조 미세캡슐 분말에서는 $\mathrm{g}$ 당 23.70 100.83 unit의 효소 활성이 나타나 위액과 장액의 $\mathrm{pH}$ 환경에서 안정성을 나타내는 것으로 확인되었다. 분무건조 미세캡슐 분말에서 말토덱스트린 단독 첨가시 $3.74 \%$ 의 낮 은 효소 안정성을 나타낸 것에 비해 말토덱스트린에 알긴산 의 첨가량이 높아질수록 효소 안정성이 높아지는 것을 확인 하였으며, 특히 알긴산 $2 \%$ 및 $3 \%$ 첨가 분말에서 각각 $14.71 \%$ 및 $15.69 \%$ 로 나타나 높은 효소 안정성을 나타냄을 확인하였다. 이는 낮은 $\mathrm{pH}$ 수용액 상태에서 용해되지 않고 팽윤 정도가 매우 작아지는 알긴산의 특성에 기인되며(34), 이를 통해 파인애플 착즙액의 protease 효소가 생체 내 위액 과 장액의 $\mathrm{pH}$ 환경에서 안정하게 통과되고 장내에서 방출 되는 효과를 나타낼 것으로 판단된다.

이와 같이 분무건조에 의한 파인애플 착즙액 미세캡슐 분말의 물리화학적 특성 및 protease 활성을 분석한 결과 말토덱스트린에 알긴산을 첨가한 구간이 우수한 물리화학 적 특성 및 protease 활성을 나타내었으며, 특히 in vitro 인체 내 소화모델에 대한 protease 활성의 안정성이 높게 나타나 기능적 특성 및 가공비용 등을 고려하였을 때 알긴 산 $2 \%$ 첨가량이 산업적으로 적용가능하다 판단된다. 
Table 4. Protease activity and in vitro dissolution of microencapsulated pineapple juice powders

\begin{tabular}{cccc}
\hline \multirow{2}{*}{ Samples ${ }^{1)}$} & $\begin{array}{c}\text { Protease activity } \\
\text { (unit/g) }\end{array}$ & \multicolumn{2}{c}{$\begin{array}{c}\text { Protease activity } \\
\text { in vitro dissolution }\end{array}$} \\
\cline { 3 - 4 } & & unit/g & $\%$ \\
\hline FD & $1,297.47 \pm 5.29^{\mathrm{a} 2)}$ & - & - \\
SD-M & $633.51 \pm 8.87^{\mathrm{c}}$ & $23.70 \pm 2.90^{\mathrm{b}}$ & $3.74 \pm 0.46^{\mathrm{c}}$ \\
SD-MA-1 & $692.08 \pm 5.98^{\mathrm{b}}$ & $41.30 \pm 5.35^{\mathrm{b}}$ & $5.97 \pm 0.77^{\mathrm{b}}$ \\
SD-MA-2 & $664.66 \pm 7.66^{\mathrm{bc}}$ & $97.75 \pm 9.46^{\mathrm{a}}$ & $14.71 \pm 1.42^{\mathrm{a}}$ \\
SD-MA-3 & $642.65 \pm 4.71^{\mathrm{c}}$ & $100.83 \pm 1.94^{\mathrm{a}}$ & $15.69 \pm 0.30^{\mathrm{a}}$ \\
\hline
\end{tabular}

${ }^{1)} \mathrm{FD}$, freeze-dried powder; SD-M, spray-dried powder added $20 \%$ maltodextrin; SD-MA-1, spray-dried powder added 20\% maltodextrin and 1\% alginic acid; SD-MA-2 spray-dried powder added 20\% maltodextrin and 2\% alginic acid; SD-MA-3, spray-dried powder added $20 \%$ maltodextrin and 3\% alginic acid.

${ }^{2}$ Means \pm SD ( $\mathrm{n}=3$ ) within each column (a-c) followed by the same letter are not significantly different $(p<0.05)$.

\section{요 약}

본 연구에서는 protease를 함유하고 있는 파인애플의 산 업적 이용 증대 및 기능성식품 소재 개발을 목적으로 분무 건조공정을 이용하여 파인애플 착즙액을 미세캡슐화 하였 으며 미세캡슐 분말의 물리화학적 특성 및 protease 활성을 조사하였다. 파인애플 착즙액의 $\mathrm{pH}$, 당도 및 protease 활성 은 각각 $\mathrm{pH} 5.43,12.80$ 및 $4.82 \mathrm{unit} / \mathrm{mL}$ 이었다. Protease 활성에 대한 최적 $\mathrm{pH}$ 및 온도는 각각 $\mathrm{pH} 7.0$ 및 $50^{\circ} \mathrm{C}$ 에서 가장 높게 분석되었다. 파인애플 착즙액의 미세캡슐분말 제조는 말토덱스트린 및 알긴산을 피복물질로 사용하여 분무건조하였으며, 수분함량은 $3.02 ~ 3.75 \%$ 였다. 색도는 분 무건조 미세캡슐 분말이 동결건조 분말에 비하여 $\mathrm{L}$ 값 및 $\mathrm{a}$ 값은 낮고 $\mathrm{b}$ 값은 높은 경향을 나타내었는데 특히 말토덱스 트린에 알긴산 $3 \%$ 첨가시 선명한 노란색을 보여주었다. 입자크기는 동결건조 분말(501.57 $\mu \mathrm{m})$ 에 비하여 분무건조 미세캡슐 분말이 42.58 53.32 $\mu \mathrm{m}$ 로 유의적으로 작고 균일 한 크기였으며, 입자모양은 전반적으로 구형의 형태를 보 여주어 분말 흐름성이 양호할 것으로 판단되었다. 수분흡 수지수는 말토덱스트린에 알긴산을 $3 \%$ 첨가한 분무건조 미세캡슐 분말에서 0.41 로 가장 낮은 지수를 나타내었으며 수분용해지수는 분무건조 미세캡슐 분말에서 98.22 $99.76 \%$ 로 나타나 동결건조 분말보다 우수하였다. 미세캡 슐 분말의 protease 활성은 동결건조 분말(1,297.47 unit/g)이 분무건조 미세캡슐 분말(633.51 692.08 unit/g)보다 유의적 으로 높은 활성을 나타내었으나, in vitro 인체 내 소화모델 에 대한 protease 활성의 안정성은 분무건조 미세캡슐 분말 에서만 $\mathrm{g}$ 당 23.70 100.83 unit의 효소 활성이 나타나 위액과 장액의 $\mathrm{pH}$ 환경에서 안정성을 나타내는 것으로 확인되었 다. 따라서 피복물질로 말토덱스트린 및 알긴산을 첨가하 여 분무건조시 식품산업 활용 측면에서 가공적성이 향상된
미세캡슐 분말의 제조가 가능하고 in vitro 인체 내 소화모델 에 대한 protease 활성의 안정성이 우수하여 기능성 식품 소재 개발에 있어 산업적으로 적용 가능할 것으로 사료된 다.

\section{감사의 글}

본 연구는 교육부와 한국연구재단의 지역혁신창의인력 양성사업으로 수행된 연구결과임(No.2013H1B8A2032215)

\section{References}

1. Bai YH, Roh JH (2000) The Properties of proteolytic enzymes in fruits (pear, kiwifruit, fig, pineapple, papaya). Korean J Soc Food Sci, 16, 363-366

2. Ministry of food and drug safety (2013) Food \& drug statistical yearbook. 15th ed, Korea, p 488

3. Kim EM, Choe IS, Hwang SG (2003) Effects of singular manner or mixed type treatment of proteases isolated from pear, pineapple and kiwifruit on actomyosin degradation. Korea J Food Sci Anim Res, 23, 193-199

4. Tappel AL, Miyada DS, Sterling C, Maier VP (1956) Meat tenderization. ПI. Factors affecting the tenderization of beef by papain. J Food Sci, 21, 375-383

5. Kim MH, Rho JH, Kim MJ (2011) Stabilizing and optimizing properties of crude protease extracted from Korean figs. Korean J Food Cookery Sci, 27, 29-37

6. Oh SJ, Kim SC, Koh SC (2002) Properties and thermostability of gelatin-degrading proteinases in the fruit of Actinidia chinensis (kiwifruit). Korean J Life Sci, $12,752-758$

7. Yang CY (2006) Physicochemical properties of chicken jerky with pear, pineapple and kiwi extracts. Korean J Culinary Res, 12, 237-250

8. Hossain MA, Rahman SMM (2011) Total phenolics, flavonoids and antioxidant activity of tropical fruit pineapple. Food Res Int, 44, 672-676

9. Mynott TL, Crossett B, Prathaling SR (2002) Proteolytic inhibition of Salmonella enterica serovar typhimurium induced activation of the mitogen-activated protein kinases ERK and JNK in cultured human intestinal cells. Infect Immun, 70, 86-95

10. Maurer HR (2001) Bromelain : biochemistry, pharmacology and medical use. Cell Mol Life Sci, 58, 1234-1245 
11. Gaspani L, Limiroli E, Ferrario P, Bianchi M (2002) In vivo and in vitro effects of bromelain on PGE (2) and SP concentrations in the inflammatory exudate in rats. Pharmacology, 65, 83-86

12. Holdsworth SD (1971) Dehydration of food products. J Food Technol, 6, 331-370

13. Manhart N, Akomeah R, Bergmeister H, Spittler A, Ploner M, Roth E (2002) Administration of proteolytic enzymes bromelain and trypsin diminish the number of $\mathrm{CD}^{+}$cells and the interferon- $\gamma$ response in Peyer's patches and spleen in endotoxemic balb/c mice. Cell Immunol, 215, 113-119

14. Park HM, No HK, Lee SH, Yoon KS, Park CS, Hong JH (2013) Quality characteristics of microencapsulated $\beta$-carotene prepared by different molecular weight chitosan. J Chitin Chitosan, 18, 26-31

15. Han MW, Yoon KS (2009) Quality characteristics of spray drying microparticulated calcium after wet-grinding. Korean J Food Sci Technol, 41, 657-661

16. Hogan SA, McNamee BF, O'Riordan ED, O'Sullivan, M (2001) Emulsification and microencapsulation properties of sodium caseinate/carbohydrate blends. Int Dairy J, 11, 137-144

17. Boatright WL, Hettiarachchy NS (1995) Spray-drided soy protein isolate solubility, gelling characteristics and extractable protein as affected by antioxidants. J Food Sci, 60, 806-809

18. Reineccius GA (1991) Carbohydrates for flavor encapsulation. Food Technol, 45, 144-150

19. Dzondo-Gadet A, Nzikou JM, Etoumongo A, Linder A, Desobry S (2005) Encapsulation and storage of safou pulp oil in 6DE maltodextrins. Process Biochem, 40, 265-271

20. Han SC, Heo EJ, Lee KY, Kim YZ, Kim JC (2003) Antioxidant effect of vitamin-C/alginate gel-entrapped liposomes for resistance of DHA autoxidation. Korean J Biotechnol Bioeng, 18, 229-233

21. Kunitz M (1947) Crystalline soybean trypsin inhibitor. J Gen Physiol 30, 291-295

22. Phillips RD, Chinnan MS, Granch AI, Miller J, Mcwatters $\mathrm{KH}$ (1998) Effects of pretreatment on functional and nutritional properties of cowpea meal. J Food Sci, 53, 805-809

23. Hur SJ, Lee SK, Kim YC, Choi IW (2012) Development of in vitro human digestion models for health functional food research. Food Sci Ind, 45, 40-49

24. Yoo SA, Seo SH, Hyun SY, Son HS (2013) Characteristics of crude protease from fruits and traditional Korean fermentation starters. J Korean Soc Food Sci Nutr, 42, 1461-1466

25. Kim MH, Rho JH, Song HN (2010) Stability and optimization of crude protease extracted from Korean kiwifruits. Korean J Food Sci Technol, 42, 554-558

26. Kim JW, Kwon YR, Yoon KS (2012) Quality characteristics and antioxidant properties in spray-dried and freeze-dried powder prepared with powdered seaweed extracts. Korean J Food Sci, 44, 716-721

27. Jeong JW, Park KJ, Kim MH, Kim DS (2006) Changes in quality of spray-dried and freeze-dried Takju powder during storage. Korean J Food Sci, 38, 513-520

28. Hwang SH, Hong JH, Jeong YJ, Yoon KS (2002) Effects of the proportions of wall materials on the characteristics of spray-dried vinegar. Korean J Food Preserv, 9, 189-193

29. Rosenberg M, Kopelman IJ, Talmon Y (1990) Factors affecting in spray-drying microencapsulation of volatile materials. J Agric Food Chem, 50, 139-144

30. Kim JW, Park IK, Yoon KS (2013) Phytochemical compounds and quality characteristics of spray-dried powders with the blanching condition and selected forming agents from pressed extracts of Ligularia fischeri leaves. Korean J Food, 20, 659-667

31. Moon JH, Kim RS, Choi HD, Kim YS (2010) Nutrient composition and physicochemical properties of Korean taro flours according to cultivars. Korean J Food Sci Technol, 42, 613-619

32. Chung HS, Hong JH, Youn KS (2005) Quality characteristics of granule prepared by protein-bound polysaccharide isolated from Agaricus blazei and selected forming agents. Korean J Food Preserv, 12, 247-251

33. Kim HR, Seog EJ, Lee JH, Rhim JW (2007) Physicochemical properties of onion powder as influenced by drying methods. J Korean Soc Food Sci Nutr, 36, 342-347

34. Pillay V, Fassihi R (1999) In vitro release modulation from crosslinked pellets for site-specific drug delivery to the gastrointestinal tract. I. Comparison of $\mathrm{pH}$-responsive drug release and associated kinetics. J Control Rel, 59, 229-242 